\title{
Temperature control of shoot growth and floral initiation in apple (Malus $\times$ domestica Borkh.)
}

\author{
Ola M. Heide ${ }^{1}$, Rodmar Rivero ${ }^{2}$ and Anita Sønsteby ${ }^{2^{*}}$ (D)
}

\begin{abstract}
Background: The environmental control of flowering in apple (Malus $x$ domestica Borkh.) has remained an enigma for generations.

Methods: We studied growth and flowering effects of temperature under daylight phytotron conditions in 3-year old 'Summerred' and 'Discovery' apple trees. Flowering was assessed by dissection of buds on spurs and extension shoots at termination of treatments and flowering performance in the subsequent spring.

Results: Exposure to constant temperatures ranging from 12 to $27^{\circ} \mathrm{C}$ for 12 weeks yielded a hyperbolic response curve with optimum at $18-21^{\circ} \mathrm{C}$ and little or no flowering at 12 and $27^{\circ} \mathrm{C}$. A drop from high to low temperature after 6 weeks caused growth cessation and initiation of flowering, whereas the reverse shift had the opposite effect. Shoot growth and leaf accumulation increased with increasing temperature, but under flower-inducing conditions, both levelled off and ceased towards the end of the treatment period.

Conclusions: The results are discussed in relation to the extensive physiological and genetic literature on the subject. We interpret the results as two separate effects of temperature on flowering in apple. At $12^{\circ} \mathrm{C}$ flowering seems to be limited by low temperature depression of growth and leaf production, while at $27^{\circ} \mathrm{C}$, flowering is blocked by inhibition of the floral initiation itself. Intermediate temperatures of $18-21^{\circ} \mathrm{C}$, on the other hand, seem to satisfy the requirements for both processes. These opposite effects of temperature have apparently confounded the understanding of the environmental control of flowering in apple.
\end{abstract}

Keywords: Apple, Critical leaf number, Dual temperature effect, Flowering, Malus domestica, Shoot growth

\section{Introduction}

The domesticated apple (Malus $\times$ domestica Borkh.) is one of the world's most important fruit crops (FAO 2017). In apple as in any other plant, flowering is an absolute prerequisite for fruit production and therefore, studies on the control of floral initiation in apple has received the attention of scientists for generations (Bangerth

\footnotetext{
*Correspondence: anita.sonsteby@nibio.no

${ }^{2} \mathrm{NIBIO}$, Norwegian Institute of Bioeconomy Research, 1431 Ås, Norway

Full list of author information is available at the end of the article
}

2006). Gur (1985) and Hanke et al. (2007) have reviewed the voluminous literature on the subject.

Floral initiation is the key developmental step that marks the process of sexual reproduction in plants. The process is proceeded by flower induction, i.e. the processing and translocation of a flower-inducing chemical signal that is perceived by the vegetative bud meristems to render them floral. The process is usually triggered by an environmental signal, but can also be endogenously controlled. Floral initiation marks the stage of no return when the first morphological changes are taking place at the shoot apical meristem (Lang 1965). During the following stage of flower differentiation, the

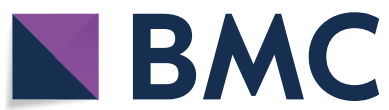

(c) The Author(s) 2020. This article is licensed under a Creative Commons Attribution 4.0 International License, which permits use, sharing, adaptation, distribution and reproduction in any medium or format, as long as you give appropriate credit to the original author(s) and the source, provide a link to the Creative Commons licence, and indicate if changes were made. The images or other third party material in this article are included in the article's Creative Commons licence, unless indicated otherwise in a credit line to the material. If material is not included in the article's Creative Commons licence and your intended use is not permitted by statutory regulation or exceeds the permitted use, you will need to obtain permission directly from the copyright holder. To view a copy of this licence, visit http://creativeco mmons.org/licenses/by/4.0/. The Creative Commons Public Domain Dedication waiver (http://creativecommons.org/publicdomain/ zero/1.0/) applies to the data made available in this article, unless otherwise stated in a credit line to the data. 
successive whorls of flower organs are then laid down at the shoot apex. Collectively, these events constitute the processes of flower bud formation (FBF).

Flowering is a complex process that is controlled by a number of internal and environmental factors (Lang 1965). In tree crops such as apple, the process is particularly complicated for several reasons. First, most woody plants including apple, have a long juvenile phase during which they cannot be induced to flower by any means (Visser 1964; Zimmerman 1972). Secondly, the annual apple shoot must develop a critical number of leaves (16-20 depending on cultivar) before it may respond to environmental factors and undergo floral initiation (Luckwill 1975; McLoughlin and Greene 1991). This means that flower bud formation may in fact be a two-step process, first a vegetative growth process to produce the critical number of nodes and secondly, the floral initiation process proper. Thirdly, there is a time span of more than 10 months between floral initiation and anthesis (blooming) in apple trees (Gur 1985; Verheij 1996), during which time the tree is going through induction and breaking of dormancy and fruits are developing in parallel with flower initiation and differentiation. These are processes that are known to interfere with FBF (Fulford Fulford 1966a, 1966b; Chan and Cain 1967). Finally, only a fraction of the buds of an apple tree becomes floral, and buds on dwarf shoots (spur buds) and buds on vigorously growing extension shoots have different seasonal timing of FBF (Zeller 1960; Jonkers 1979; Rivero et al. 2017). In addition, because of its size, the apple tree does not lend itself readily for experimentation in controlled environments.

Environmental conditions are known to influence FBF in apple, but experimental results have often been inconsistent and highly variable (Gur 1985; Hanke et al. 2007). Shading (reduced light flux) has long been known to strongly reduce flowering in apple trees (Auchter et al. 1926; Paddock and Charles 1928; Jackson and Palmer 1977; Tromp 1984). Shading to $37 \%$ of full sunlight reduced flowering to $44 \%$ of the control (Chain 1973), and reduction to $30 \%$ of full sunlight was reported as the threshold level for FBF in apple (Lakso 1980). In contrast, photoperiod does not affect FBF in apple (Hoyle 1955; Gorter 1955, 1965; Piringer and Downs 1959). Although Tromp (1984) found that FBF was better in $14 \mathrm{~h}$ long day (LD) than in $8 \mathrm{~h}$ short day (SD) conditions, he concluded that the result was due to differences in daily light integral, which was almost twice as large in LD as in the SD treatment. It was also demonstrated by Heide and Prestrud (2005) that vegetative growth cessation and dormancy induction are likewise unaffected by photoperiod in apple, but rather controlled by low temperature.
Several studies have examined the effect of temperature on FBF in apple. Abbott et al. (1975) found that in southern England, elevated spring temperature up to $18{ }^{\circ} \mathrm{C}$ from the stage of full bloom enhanced FBF, while low temperature $\left(11^{\circ} \mathrm{C}\right.$ day $/ 7^{\circ} \mathrm{C}$ night $)$ was favourable in autumn (Abbott and Bull 1973). In controlled environments, Tromp (1976) found that shoot growth of 'Cox's Orange Pippin' apple trees was reduced while FBF was stimulated at 17 or $19{ }^{\circ} \mathrm{C}$ compared with $24{ }^{\circ} \mathrm{C}$ when applied from full bloom. Raising the temperature from 17 to $24{ }^{\circ} \mathrm{C}$ late in the experimental period also reduced FBF. However, although growth was similarly reduced by low temperature in 'Golden Delicious', flowering was unaffected in this cultivar. In a later experiment with the same cultivars, Tromp (1980) divided the period after full bloom into tree equal periods of 5-6 weeks each and varied the temperature between 17 and $24{ }^{\circ} \mathrm{C}$ in these three periods, but with no consistent effects on FBF in either cultivar. It should be noticed, however, that these experiments were primarily planned for investigation of other processes than FBF, and that in the first experiment; fruits were present on the trees, while the trees were de-blossomed before experimentation in the second experiment. In another study with 'Cox's Orange Pippin' (Tromp 1984), it was confirmed that low temperature $\left(16 / 12{ }^{\circ} \mathrm{C}, \mathrm{D} / \mathrm{N}\right)$ for the first $8-9$ weeks after bloom reduced shoot growth and enhanced FBF compared with higher temperature $\left(22 / 18{ }^{\circ} \mathrm{C}\right)$ for the same period. Increase or decrease in temperature after the first 6-7 weeks had little effect on either growth or flowering. At a day temperature of $18{ }^{\circ} \mathrm{C}$, shoot growth increased linearly with increasing night temperature ranging from $6{ }^{\circ} \mathrm{C}$ to $30{ }^{\circ} \mathrm{C}$, while flowering had an optimum at $18{ }^{\circ} \mathrm{C}$ and with a marked reduction at $30^{\circ} \mathrm{C}$ night temperature. Later, Zhu et al. (1997) studied the effect of three temperatures $\left(13,20\right.$, and $\left.27{ }^{\circ} \mathrm{C}\right)$ applied continuously for 18 weeks in cv. Summerred, starting 1 week after full bloom, or changed after 5 weeks in the following ways: 13 then $20{ }^{\circ} \mathrm{C}$; 20 then $27{ }^{\circ} \mathrm{C}$; and 27 then $13{ }^{\circ} \mathrm{C}$. Contrary to earlier studies by Tromp $(1976,1980,1984)$, FBF was in this experiment stimulated by intermediate and high temperature when applied for the whole season as well as when applied for 6 weeks from full bloom, in both spurs and elongation shoots. This temperature enhancement of FBF was most pronounced in the $13-20{ }^{\circ} \mathrm{C}$ range. Lowering the temperature from 27 to $13{ }^{\circ} \mathrm{C}$ after 5 weeks resulted in immediate growth cessation but markedly reduced flowering. Controlled environment experiments by Verheij (1996) also produced inconsistent and sometimes opposing effects of temperature. In cv. Jonagold, FBF was slightly enhanced by $13{ }^{\circ} \mathrm{C}$ compared with 21 and $27^{\circ} \mathrm{C}$, while the opposite effect was found in 'Cox's Orange Pippin' at $13{ }^{\circ} \mathrm{C}$ compared with $24{ }^{\circ} \mathrm{C}$. 
The conclusion is therefore, that the effect of temperature on FBF has been highly variable and inconsistent, and in addition, the effect seems to vary among cultivars.

Another important question is, at what time of the growing season the apple shoot is receptive for induction by temperature and other environmental factors. The issue has been studied by applying flower-inhibiting treatments such as defoliation or shading at various times during the growing season, assuming that inhibition should be maximal at the time when floral initiation takes place and no longer are reversible. Experiments of this kind in eastern USA indicated the period up to 61 and 110 days after full bloom as critical with some variation between cultivars (Magness et al. 1933), while the period up to 42 days after bloom was found to be most important for cv. Winter Sunshine in England (Davies 1959). Tromp $(1976,1980)$ concluded that under controlled environment conditions, temperature during the first 4-5 weeks after full bloom appeared to be especially important for FBF, while Zhu et al. (1997) found that the period 6-7 weeks after full bloom had the greatest effect although temperature conditions during the entire growing season affected FBF. Dissection of buds collected in the field (Singh 1948; Jonkers 1979; Rivero et al. 2017) revealed that in spur buds, floral initiation takes place 6-8 weeks after full bloom, while in buds on extension shoots, it takes place at least 2-3 weeks later. Foster et al. (2003) found that broadening of the shoot apex, which they considered the first visible sign of floral commitment, occurs between 39 and 53 days after full bloom. In contrast, Hanke (1981) who investigated spur buds and buds on elongation shoots of 'Golden Delicious' over a period of 3 years, concluded that the occurrence of the various ontogenetic stages was not related to the date of full bloom, but rather seemed to be determined by calendar day. Thus, the temporal floral induction window in apple is not well defined, but seems to vary considerably between cultivars and types of buds.

It is commonly considered that there is an antagonistic relationship between vegetative growth and flowering in apple trees (Luckwill 1970; Crabbé 1984; Forshey and Elfing 1989). Although it has been reported that floral initiation can take place before shoot growth has ceased (Zeller 1960; Hanke et al. 2007), it is generally accepted that initiation in extension shoots usually takes place after the cessation of shoot growth (Luckwill 1970; Hanke et al. 2007). Despite the frequent antagonistic association of growth and FBF in apple, independent control of the two processes has also been reported in some studies (e.g. Zhu et al. 1997; Verheij 1996). Much attention has also been paid to the importance of the plastochron (the time interval between formation of successive leaves by the apical meristem) for the formation of flower buds in apple (Fulford 1965, 1966a, 1966b). It was considered that environmental manipulations that affect FBF do so via their influence on the plastochron, and that a plastochron of 5-7 days is optimal for FBF, whereas greater lengths are inhibitory. However, no underlying mechanism of action has been suggested and doubts have been raised about the validity of the plastochron theory (e.g. Luckwill and Silva 1969; Hanke et al. 2007). Verheij (1996) found that although a range of treatments affected FBF, the plastochron was only affected by temperature and defoliation. He therefore concluded that the plastochron is not a critical factor for the occurrence of flower bud formation.

With the advent of modern molecular biology, there has been rapid progress in the understanding of the genetic control of FBF in apple. Several genes have been identified in apple that are considered putative homologs to genes that regulate vegetative growth and floral transition in the annual model plant Arabidopsis thaliana (Hanke et al. 2007; Kotoda et al. 2010; Mimida et al. 2011; Flachowsky et al. 2012). Today, more is actually known about the genes that are associated with FBF in apple, than about the environmental factors that are triggering the activation of these genes (Kurokura et al. 2013).

In an attempt to provide more information on the environmental control of FBF in apple trees, we have studied the effects of a range of temperature conditions on threeyear-old trees of 'Summerred' and 'Discovery' grown under natural daylength conditions in daylight phytotron compartments in the years 2016 and 2017. Based on earlier results reported in the literature, we expected to observe both direct and indirect (growth-dependent) effects of temperature on flower bud formation in apple that might shed new light on the underlying mechanisms. By exposing trees to the whole range of relevant temperatures, we anticipated to observe both stimulatory and inhibitory flowering responses.

\section{Materials and methods \\ Plant material and cultivation}

Two-year old bare root trees of the cultivars 'Summerred' and 'Discovery' grafted on M4 rootstocks were purchased from a commercial nursery and used for experimentation in their third year of growth. Both cultivars are known to readily form lateral flower buds on extension shoots (Rivero et al. 2017). After overwintering in a $2{ }^{\circ} \mathrm{C}$ cold store, the trees were potted in $7.5 \mathrm{l}$ plastic pots in a peat based potting compost (Gartnerjord, LOG, Oslo, Norway) in late April and moved outdoors at the NIBIO experimental center Apelsvoll $\left(60^{\circ} 40^{\prime} \mathrm{N}, 10^{\circ} 52^{\prime} \mathrm{E}, 150 \mathrm{~m}\right.$ asl.). During the last day before potting, the trees were soaked with their roots in water. On 1 June, when the trees had started flowering, the trees were moved into the natural 
Table 1 Temperature treatments applied to 'Summerred' and 'Discovery' apple trees in the years 2016 and 2017

\begin{tabular}{|c|c|}
\hline Year 2016 & Year 2017 \\
\hline $12^{\circ} \mathrm{C}$ constant for 12 weeks & $12^{\circ} \mathrm{C}$ constant for 12 weeks \\
\hline $15^{\circ} \mathrm{C}$ constant for 12 weeks & $18^{\circ} \mathrm{C}$ constant for 12 weeks \\
\hline $18^{\circ} \mathrm{C}$ constant for 12 weeks & $24^{\circ} \mathrm{C}$ constant for 12 weeks \\
\hline $21^{\circ} \mathrm{C}$ constant for 12 weeks & $27^{\circ} \mathrm{C}$ constant for 12 weeks \\
\hline $12^{\circ} \mathrm{C}$ for $6 \mathrm{w}$. - then $18^{\circ} \mathrm{C}$ for $6 \mathrm{w}$. & $12^{\circ} \mathrm{C}$ for $6 \mathrm{w}$. - then $24^{\circ} \mathrm{C}$ for $6 \mathrm{w}$. \\
\hline $15^{\circ} \mathrm{C}$ for $6 \mathrm{w}$. - then $21^{\circ} \mathrm{C}$ for $6 \mathrm{w}$. & $18^{\circ} \mathrm{C}$ for $6 \mathrm{w}$. - then $27^{\circ} \mathrm{C}$ for $6 \mathrm{w}$. \\
\hline $18^{\circ} \mathrm{C}$ for $6 \mathrm{w}$. - then $12{ }^{\circ} \mathrm{C}$ for $6 \mathrm{w}$. & $24^{\circ} \mathrm{C}$ for $6 \mathrm{w}$. - then $12^{\circ} \mathrm{C}$ for $6 \mathrm{w}$. \\
\hline $21^{\circ} \mathrm{C}$ for $6 \mathrm{w}$.- then $15^{\circ} \mathrm{C}$ for $6 \mathrm{w}$. & $27^{\circ} \mathrm{C}$ for $6 \mathrm{w}$. - then $18^{\circ} \mathrm{C}$ for $6 \mathrm{w}$. \\
\hline
\end{tabular}

daylight phytotron at the Norwegian University of Life Sciences at $\AA$ s $\left(59^{\circ} 40^{\prime} \mathrm{N}, 10^{\circ} 45^{\prime} \mathrm{E}\right)$ and distributed to four daylight compartments and exposed to natural daylength conditions at temperatures as shown in Table 1. The results of the 2016 experiments prompted us to broaden the temperature range in 2017. Space limitations in the four available compartments limited the number of temperature combinations and replications that could be accommodated. At transfer to the phytotron, the trees were trimmed down to 4-5 main branches, which were cut back to approximately one-third of their original length and all flowers were removed. Temperatures in the phytotron were controlled to $\pm 1.0^{\circ} \mathrm{C}$, and a vapour pressure deficit of $530 \mathrm{~Pa}$ was maintained at all temperatures. Whenever the photosynthetic photon flux (PPF) fell below approximately $150 \mu \mathrm{mol}$ quanta $\mathrm{m}^{-2} \mathrm{~s}^{-1}$ (as on cloudy days), an additional $125 \mu \mathrm{mol}$ quanta $\mathrm{m}^{-2} \mathrm{~s}^{-1}$ were automatically added using Philips HPT-1 $400 \mathrm{~W}$ lamps. One set of trees were also left outside at NIBIO Apelsvoll at ambient temperature and light conditions as a control for comparison with the phytotron treatments. Temperature conditions at Apelsvoll in the 2 years are shown in Fig. 1.

Throughout cultivation, the trees were watered as needed with a fertilizer solution with electric conductivity of $1.5 \mathrm{mS} \mathrm{cm}^{-1}$ and consisting of a $2: 3$ mixture of Superba $\operatorname{Red}^{\mathrm{TM}}$ (7-4-22\% NPK + micronutrients) and Calcinit $^{\mathrm{TM}}(15.5 \% \mathrm{~N}$ and 19\% Ca), both from Yara International (Oslo, Norway). Two broad spectrum fungicides (Nordox 75 WG, Plant Food Company Inc., USA, and Topas 100 EC, Syngenta, UK) and one insecticide spraying (Calypso, Bayer Crop Science, UK) were applied during the first week after potting. The trees were also sprayed with a Thiovit elemental sulphur suspension for protection against mildew at start and every third week during experimentation. Biological control with A. cucumeris was applied at start and 3-4 times during the experimentation against spider mites and trips. In 2017,

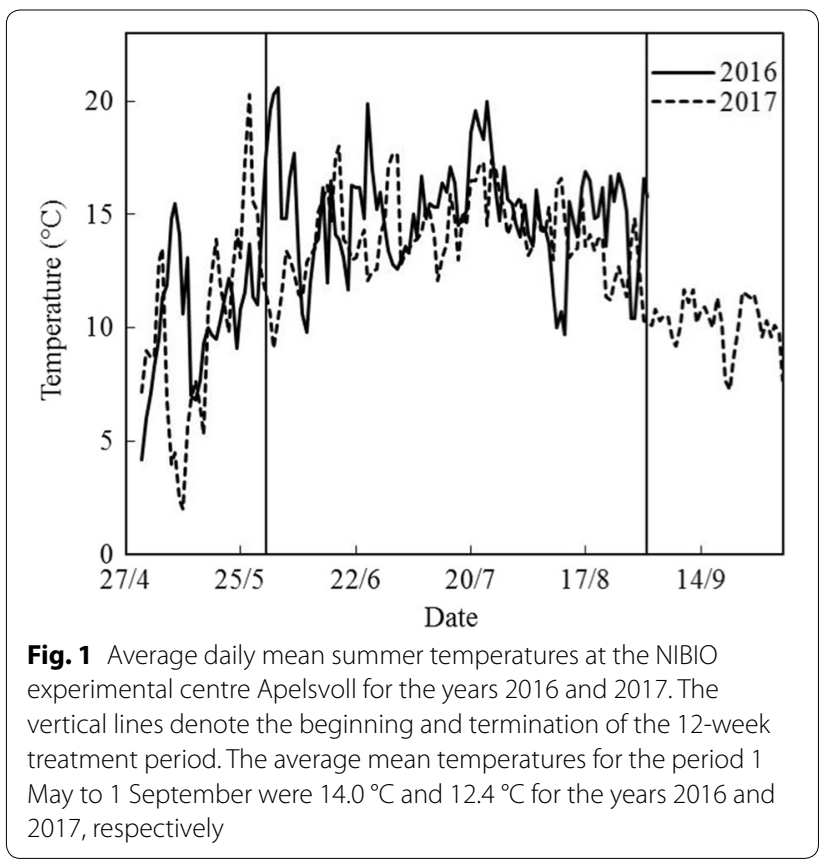

after completion of the 12-week experimental treatments in the phytotron on 1 September, two trees of each treatment were moved back to Apelsvoll where they were defoliated and placed directly in a $1{ }^{\circ} \mathrm{C}$ cold store. This ensured dormancy induction and release without affecting flowering state. After overwintering at $1{ }^{\circ} \mathrm{C}$ in darkness until late April, they were then returned to outdoor conditions where they remained until blooming and recording of flowering performance.

\section{Experimental design and data collection}

Each treatment consisted of five trees, which were treated as replicates in the statistical analyses. Shoot elongation growth was monitored by weekly recordings of the length and the number of leaves of the leading (longest) shoot of each tree during the 12-week experimental period. Flowering was assessed by dissection of buds sampled after completion of the 12-week treatments at the various temperature conditions in both years, and in 2017 also by recording of flowering performance of two trees in each treatment in the following spring after overwintering at $1{ }^{\circ} \mathrm{C}$. In 2016, the dissections included all spur buds as well as all lateral buds along the entire length of five extension shoots (including the measured shoot) from each of the five trees in each treatment. The number of dissected buds varied between 60 and 130 per tree, depending on number and size of the shoots. A total of 1900 buds were dissected in the 2016 experiment. In 2017, all spur buds ( $0-20$ per tree) on three randomly selected trees 
were likewise dissected in each treatment, while for reduction of the workload, only 5 lateral buds from the mid zone of each of the three longest current season extension shoots of the same three selected trees were dissected and examined (total of 15 buds per tree). The sampled buds were either dissected fresh or fixed and stored on $70 \%$ ethanol until dissection and determination of their flowering stage under a stereo microscope according to the 7-stage scale of morphological changes used by Foster et al. (2003) and Rivero et al. (2017). Scanning electron microscopy images as presented by Rivero et al. (2017) were used for assessment of the floral stages (see Fig. 2). In both years, we also sampled and dissected 2-3 buds from each treatment after 6 weeks of treatment in order to get an indication of the early progression of flower formation. At bloom time in the following spring in 2018, the total number of flower clusters (inflorescences) and the total number of flowers were determined in the remaining two trees per treatment that was overwintered in the cold store at Apelsvoll. In these trees, no buds had been sampled in the previous autumn.

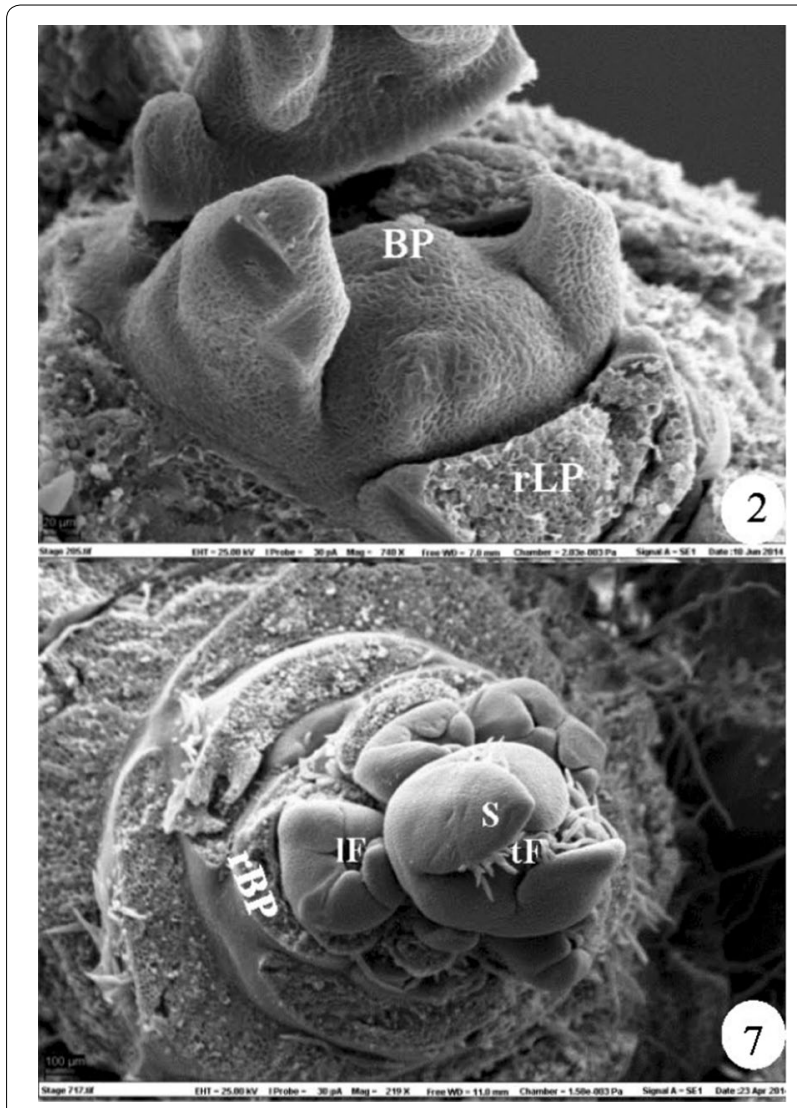

Fig. 2 Scanning electron microscopy images of floral stages 2 and 7 in apple. (From Rivero et al. 2017)

\section{Statistical analysis}

Experimental data for shoot length and leaf numbers after 6 weeks and flowering (dissection results and spring flowering) were subjected to two-way analysis of variance (ANOVA) by standard procedures, while Tukey's multiple comparison test was used to assess the significance of differences between means. All analyses were performed using the Minitab ${ }^{\circledR}$ Statistical Software program package (Release 17.1.0. Minitab. Inc., State College, PA, USA). All percentage values (proportion of floral buds) were subjected to an arc sin transformation before performance of the ANOVA.

\section{Results}

\section{Shoot growth and leaf accumulation}

In both years, shoot growth rate generally increased with increasing temperature during the first 6 weeks of "free" growth, but usually with little increase at temperatures above $18{ }^{\circ} \mathrm{C}$ (Figs. 2, 3a, c). With the higher temperatures applied in 2017, growth increased with increasing temperature up to $24{ }^{\circ} \mathrm{C}$, with no or little further increase at $27{ }^{\circ} \mathrm{C}$. Under outdoor conditions at Apelsvoll, shoot growth was intermediate between that at $12{ }^{\circ} \mathrm{C}$ and $15{ }^{\circ} \mathrm{C}$ in the phytotron in 2016, while in 2017, growth was quite similar to that at $12{ }^{\circ} \mathrm{C}$ in the phytotron. An ANOVA analysis of shoot length data after 6 weeks of growth revealed a highly significant effect $(P<0.001)$ of temperature in both years. However, only the mean values for trees grown at $12{ }^{\circ} \mathrm{C}$ and at ambient temperatures were significantly different from the rest. Since shoot growth started to level off after 6 weeks at the higher temperatures while continuing at lower temperatures, differences in final shoot length gradually diminished and final length was not significantly different after 12 weeks in the 2016 experiment (Fig. 3). However, with the extended temperature range used in 2017, also the final shoot length increased significantly $(P=0.001)$ with increasing temperature in both cultivars (Fig. 4).

Although the trees of 'Summerred' elongated almost twice as much as those of 'Discovery', the temperature effect on shoot length and leaf number was similar in the cultivars (no significant cultivar $\mathrm{x}$ temperature interaction). The higher outdoor temperature in 2016 (Fig. 1) resulted in slightly greater shoot growth under ambient conditions in 2016 than in 2017 in the cultivar 'Discovery' but not in 'Summerred'. It should be noticed, however, that except for the 24 and $27{ }^{\circ} \mathrm{C}$ treatments in 2017, shoot growth usually levelled off or ceased completely in late July, after 6-7 weeks of treatment (Figs. 3, 4). Generally, this took place earlier at intermediate than at constant low or high temperatures. When the temperature was shifted to higher 

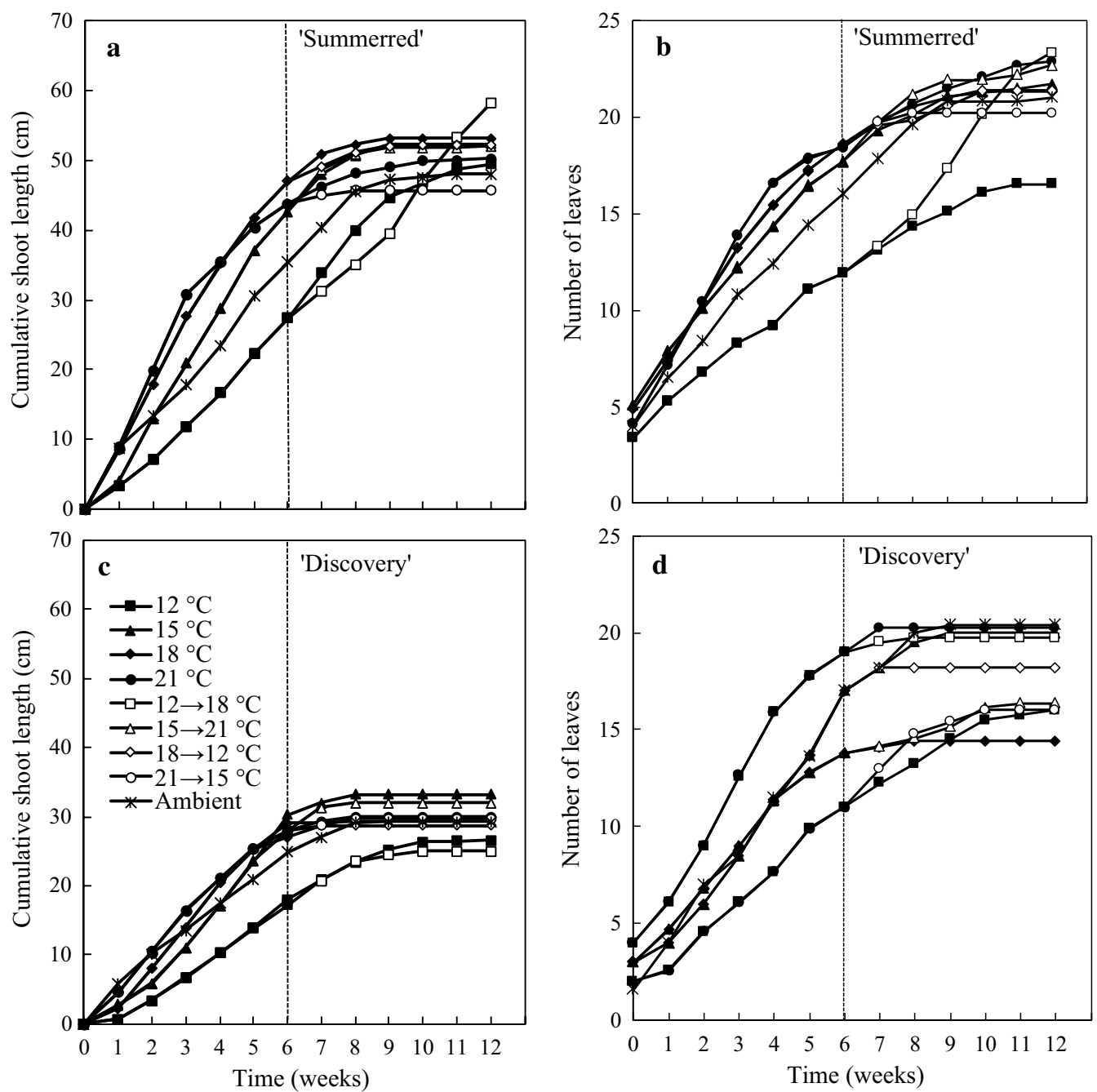

Fig. 3 Time courses of shoot elongation growth (Panels $\mathbf{a}, \mathbf{c}$ ), and the accumulation of leaves (Panels $\mathbf{b}$, $\mathbf{d}$ ) for the leading shoot of apple trees of the cultivars 'Summerred' and 'Discovery' as affected by the indicated temperature treatments under natural light conditions at Ås, Norway, in the year 2016. The vertical lines at 6 weeks of treatment correspond to 13 July. Each point represents the mean of 10 trees for the first 6 weeks of treatment, and of 5 trees for the next 6 weeks

levels after 6 weeks of low temperature, growth usually (but not always) increased afterwards, while a shift from high to low temperature resulted in reduced growth or complete growth cessation. These growth changes were most marked with the larger temperature shifts applied in 2017. Thus, in plants grown at 24 or $27^{\circ} \mathrm{C}$ for 6 weeks and then shifted to 12 or $18{ }^{\circ} \mathrm{C}$, respectively, an immediate cessation of growth took place (Fig. 4a, c).

The effect of temperature on the cumulative increase in leaf (node) numbers was also highly significant $(P=0.001)$ in both years and closely paralleled the effects of temperature on elongation growth for the first 6-7 weeks (Figs. 3, 4b, d).

\section{Flowering}

Dissection of 2-3 randomly selected buds after 6 weeks of treatment revealed that transition to generative development had started in some trees at 18 and $21{ }^{\circ} \mathrm{C}$ at this stage in both years, while no changes were observed at the other temperatures (data not shown). Dissections after 12 weeks of cultivation at the various constant temperatures revealed consistent and highly significant $(P<0.001)$ effects of temperature on floral initiation in both cultivars (Figs. 5, 6). In both years, no lateral buds on extension shoots and spurs had initiated floral primordia at $12{ }^{\circ} \mathrm{C}$ in any of the cultivars, except in 2016 , when about one-third (35\%) of the spur buds of 'Summerred' had reached an early stage of FBF at this temperature. At 

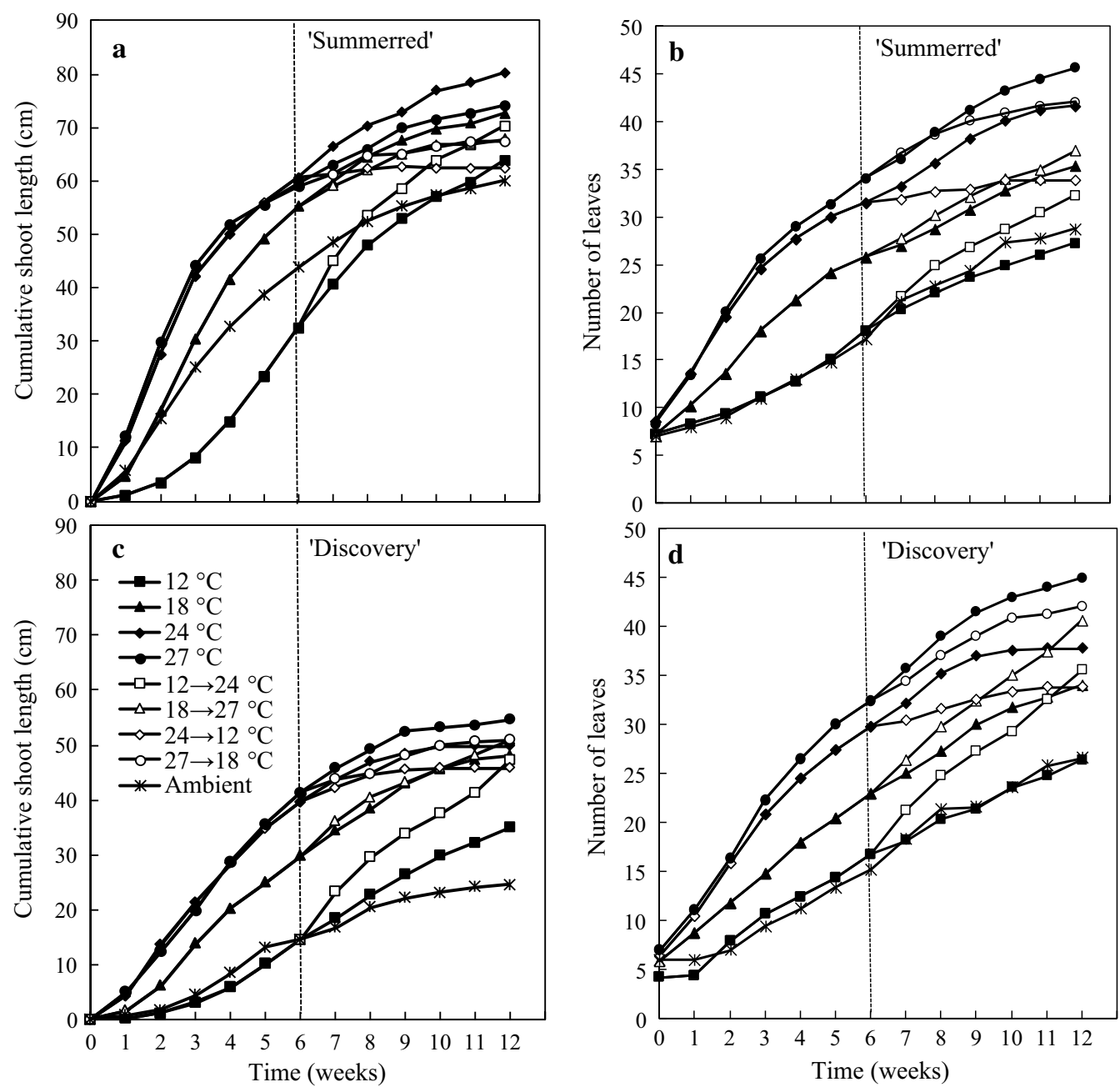

Fig. 4 Time courses of shoot elongation growth (Panels $\mathbf{a}, \mathbf{c}$ ), and the accumulation of leaves (Panels $\mathbf{b}$, $\mathbf{d}$ ) for the leading shoot of apple trees of the cultivars 'Summerred' and 'Discovery' as affected by the indicated temperature treatments under natural light conditions at Ås, Norway, in the year 2016. The vertical lines at 6 weeks of treatment correspond to 13 July. Each point represents the mean of 10 trees for the first 6 weeks of treatment, and of 5 trees for the next 6 weeks

higher temperatures, the proportion of buds with floral primordia increased sharply to an optimum at $18-21{ }^{\circ} \mathrm{C}$ in both spur buds and extension shoots. At still higher temperatures in 2017, the proportion of generative buds decreased again at $24{ }^{\circ} \mathrm{C}$, and further on to a very low level at $27{ }^{\circ} \mathrm{C}$ (Fig. 5). These effects were associated with parallel changes in the stage of floral bud development (Fig. 6). Generally, the trees grown outdoors had an intermediate flowering response to those grown at 12 and $15{ }^{\circ} \mathrm{C}$ in the phytotron (Tables 2, 3). Higher outdoor temperatures in 2016 than in 2017 (Fig. 1), was reflected in more advanced out-door flower development in 2016 (Tables 2, 3). In both cultivars, floral initiation was less advanced in extension shoots than in spurs, while initiation in extension shoots was consistently more advanced in 'Summerred' than in 'Discovery'. Otherwise, the two cultivars responded rather similarly to the constant temperature treatments.

The same trend in the temperature flowering response was observed in the trees that were transferred to higher or lower temperatures after 6 weeks. Although the results were somewhat variable at the lower temperature range tested in 2016, the results in 2017 when the wider range of temperatures was used, showed a marked and consistent enhancement of flowering when the temperature was shifted from high to low temperature (Tables 2, 3). Such a drop in temperature, which caused an immediate growth cessation (Fig. 4), was consistently more conducive to flowering than was constant high temperature or the parallel shift from low to high temperature. Overall, the temperature effect was more pronounced in 'Discovery' than in 'Summerred' in both years (Tables 2, 3). 

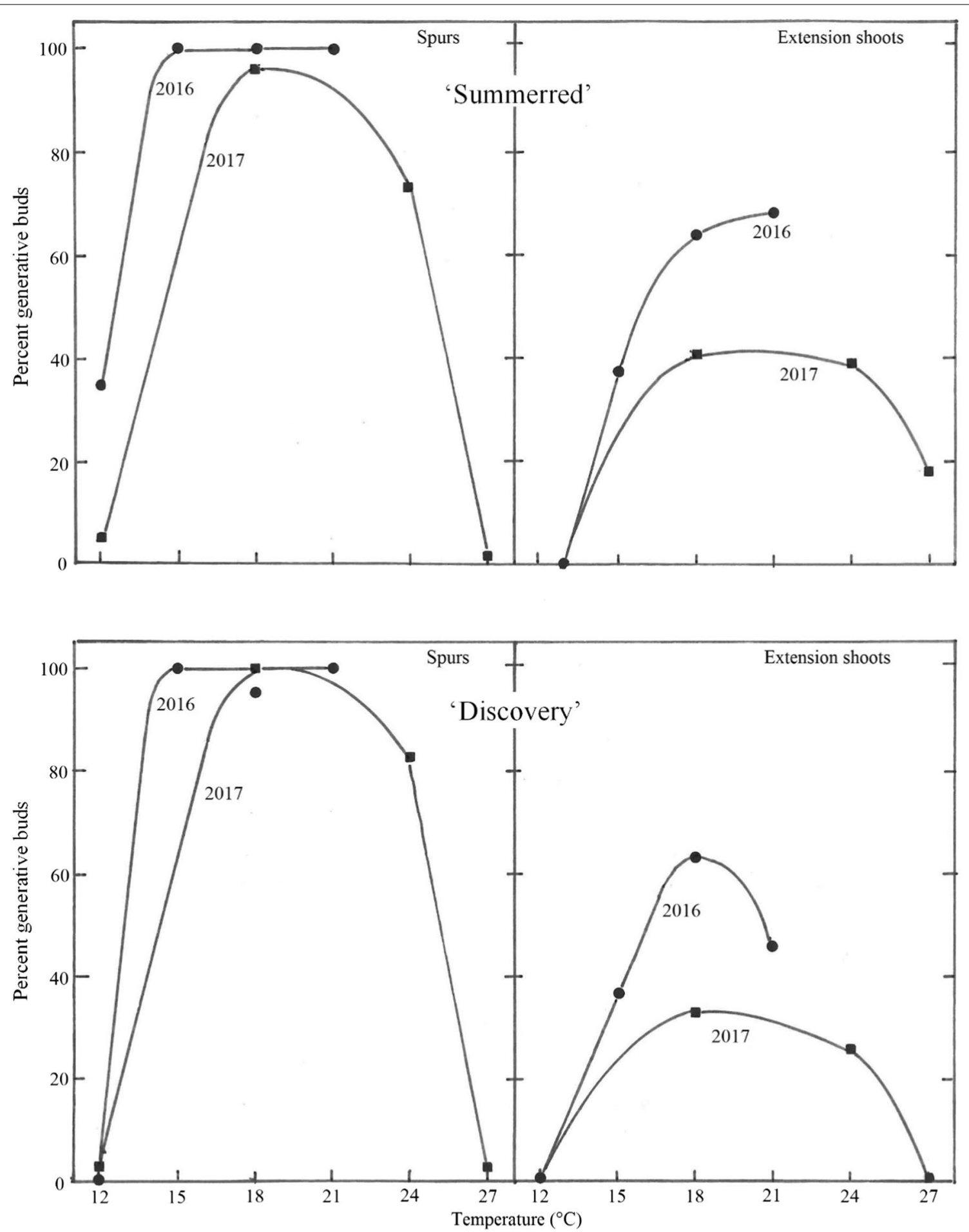

Fig. 5 Percentage of generative buds in spurs and extension shoots of the apple cultivars 'Summerred' and 'Discovery' as influenced by 12 weeks of exposure to various constant temperatures as indicated in the years 2016 and 2017. Each point represents the mean of 5 trees in 2016 and 3 trees in 2017 

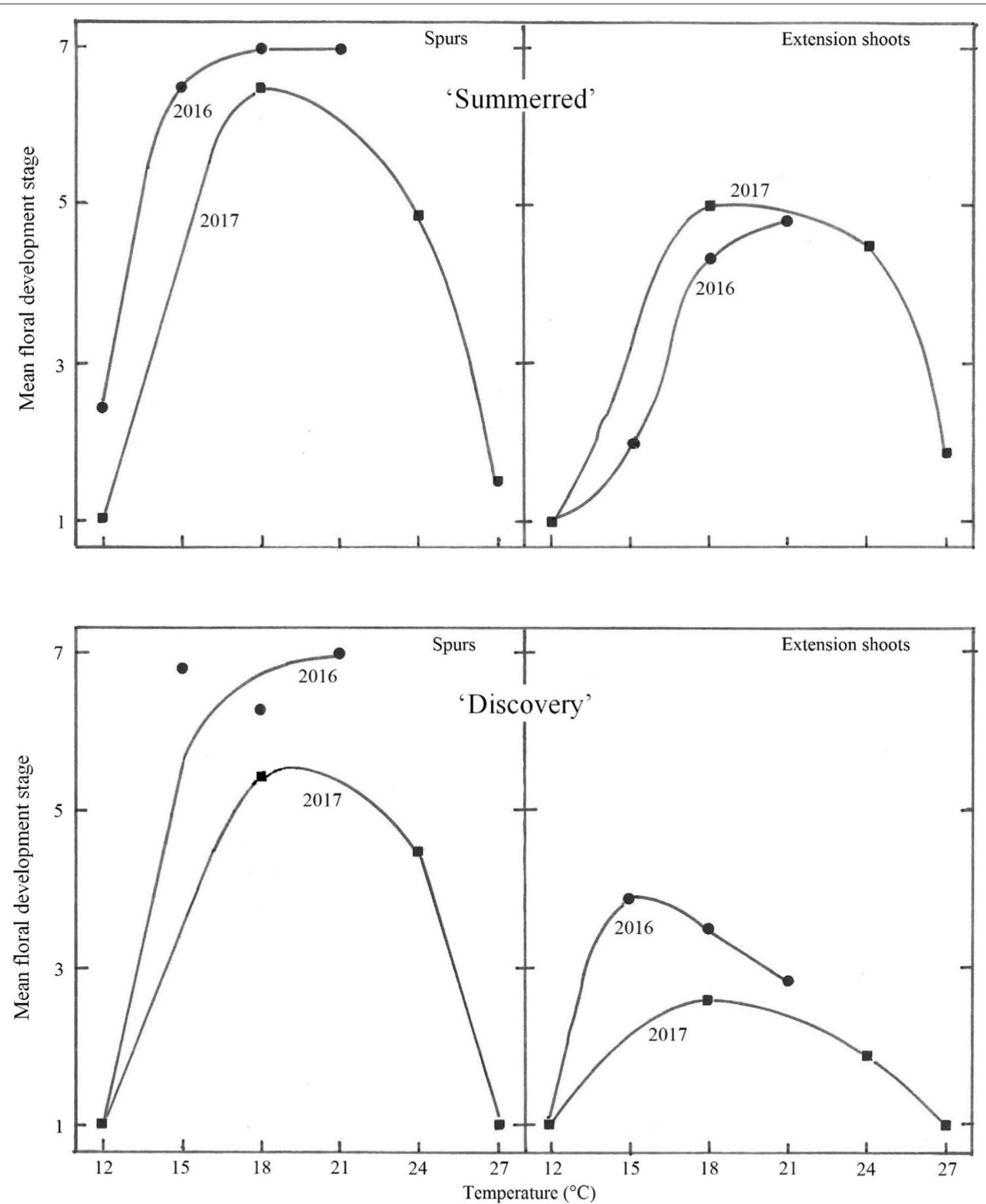

Fig. 6 Mean floral development stages of dissected buds of spurs and extension shoots of the apple cultivars 'Summerred' and 'Discovery' as influenced by 12 weeks of exposure to various constant temperatures as indicated in the years 2016 and 2017. Stage 1 denotes entirely vegetative buds and stage 7 denotes fully differentiated primary flowers. Each point represents the mean of 5 trees in 2016 and of 3 trees in 2017

Flowering of the trees from the 2017 experiment that were overwintered and allowed to flower in the 2018 season were also significantly and consistently affected by both constant and changing temperatures (Table 4).
With one exception, both percentage of flowering nodes and the number of flowers per tree and per flower cluster, mirror the results obtained by dissections performed at termination of the treatments in the previous autumn, 
Table 2 The influence of constant and changing temperatures on the percentage of reproductive buds and the mean floral development stage of dissected buds of spurs and extension shoots of the apple cultivars 'Summerred' and 'Discovery' after completion of 12 weeks of exposure to the indicated temperatures (2016 experiment)

\begin{tabular}{|c|c|c|c|c|c|}
\hline \multirow[t]{2}{*}{ Cultivar } & \multirow[t]{2}{*}{ Temperature $\left({ }^{\circ} \mathrm{C}\right)$} & \multicolumn{2}{|l|}{ Spurs } & \multicolumn{2}{|l|}{ Extension shoots } \\
\hline & & $\begin{array}{l}\text { Generative buds } \\
\text { (\%) }\end{array}$ & $\begin{array}{l}\text { Mean floral development } \\
\text { stage }(1-7)^{\mathrm{a}}\end{array}$ & $\begin{array}{l}\text { Generative buds } \\
\text { (\%) }\end{array}$ & $\begin{array}{l}\text { Mean floral } \\
\text { development } \\
\text { stage (1-7) }\end{array}$ \\
\hline \multirow[t]{9}{*}{ 'Summerred' } & $12^{\circ} \mathrm{C}$ cont. & $35.0 b^{b}$ & $2.3 c$ & $0.0 \mathrm{~d}$ & $1.0 \mathrm{~d}$ \\
\hline & $15^{\circ} \mathrm{C}$ cont. & $100 \mathrm{a}$ & $6.6 b$ & $37.4 c$ & $2.0 \mathrm{c}$ \\
\hline & $18^{\circ} \mathrm{C}$ cont. & $100 \mathrm{a}$ & $7.0 \mathrm{a}$ & $63.5 \mathrm{a}$ & $4.4 \mathrm{a}$ \\
\hline & $21^{\circ} \mathrm{C}$ cont. & $100 \mathrm{a}$ & $7.0 \mathrm{a}$ & $67.2 \mathrm{a}$ & $4.7 \mathrm{a}$ \\
\hline & Ambient & $100 \mathrm{a}$ & $6.8 \mathrm{ab}$ & $64.6 b$ & $3.5 b$ \\
\hline & $12 \longrightarrow 18^{\circ} \mathrm{C}$ & $94.4 \mathrm{~A}$ & $6.0 \mathrm{~B}$ & $51.1 \mathrm{~B}$ & $2.6 \mathrm{D}$ \\
\hline & $15 \longrightarrow 21^{\circ} \mathrm{C}$ & $92.3 \mathrm{~A}$ & $6.8 \mathrm{~A}$ & $66.9 \mathrm{~A}$ & $5.0 \mathrm{~A}$ \\
\hline & $18 \longrightarrow 12^{\circ} \mathrm{C}$ & $100 \mathrm{~A}$ & $7.0 \mathrm{~A}$ & $66.1 \mathrm{~A}$ & $4.2 \mathrm{C}$ \\
\hline & $21 \longrightarrow 15^{\circ} \mathrm{C}$ & $100 \mathrm{~A}$ & $7.0 \mathrm{~A}$ & $66.5 \mathrm{~A}$ & $4.6 \mathrm{~B}$ \\
\hline \multirow[t]{9}{*}{ 'Discovery' } & $12^{\circ} \mathrm{C}$ cont. & $0.0 \mathrm{~d}$ & $1.1 \mathrm{e}$ & $1.5 \mathrm{e}$ & $1.1 \mathrm{e}$ \\
\hline & $15^{\circ} \mathrm{C}$ cont. & $100 \mathrm{a}$ & $6.8 b$ & $36.4 c$ & $3.9 \mathrm{a}$ \\
\hline & $18^{\circ} \mathrm{C}$ cont. & $94.4 b$ & $6.4 c$ & $62.8 \mathrm{a}$ & $3.6 b$ \\
\hline & $21^{\circ} \mathrm{C}$ cont. & $100 \mathrm{a}$ & $7.0 \mathrm{a}$ & $45.3 b$ & $2.7 c$ \\
\hline & Ambient & $75.0 \mathrm{C}$ & $2.7 d$ & $28.2 \mathrm{~d}$ & $1.7 \mathrm{~d}$ \\
\hline & $12 \longrightarrow 18^{\circ} \mathrm{C}$ & $64.3 \mathrm{~B}$ & $2.7 \mathrm{D}$ & $49.3 \mathrm{C}$ & $1.8 \mathrm{~B}$ \\
\hline & $15 \longrightarrow 21{ }^{\circ} \mathrm{C}$ & $100 \mathrm{~A}$ & $3.7 C$ & $53.4 \mathrm{~A}$ & $2.2 \mathrm{~B}$ \\
\hline & $18 \longrightarrow 12^{\circ} \mathrm{C}$ & $100 \mathrm{~A}$ & $6.7 \mathrm{~A}$ & $51.4 \mathrm{~B}$ & $3.1 \mathrm{~A}$ \\
\hline & $21 \longrightarrow 15^{\circ} \mathrm{C}$ & $85.7 \mathrm{AB}$ & $6.1 \mathrm{~B}$ & $51.8 \mathrm{~B}$ & $3.3 \mathrm{~A}$ \\
\hline \multicolumn{6}{|c|}{ Probability level of significance by ANOVA } \\
\hline \multicolumn{6}{|c|}{ Source of variation } \\
\hline \multicolumn{2}{|c|}{ Cultivar (A) } & $<0.001$ & $<0.001$ & 0.001 & 0.001 \\
\hline \multicolumn{2}{|c|}{ Temperature (B) } & $<0.001$ & $<0.001$ & $<0.001$ & $<0.001$ \\
\hline \multicolumn{2}{|l|}{$A \times B$} & $<0.001$ & $<0.001$ & $<0.001$ & $<0.001$ \\
\hline
\end{tabular}

The data are means of all spur buds from each of the five replicate trees and of all lateral buds along the entire length of five extension shoots from each tree

a Stage 1 denotes entirely vegetative buds, and stage 7 denotes fully differentiated primary flowers

b For separation of means, Tukey's multiple comparison test was performed separately for the two cultivars (lower case letters), and likewise for constant and changing temperatures (capital letters)

and again flowering was very poor in the trees exposed to 12 and $27^{\circ} \mathrm{C}$ as well as ambient temperature. However, in both cultivars, the trees that were transferred from 24 to $12{ }^{\circ} \mathrm{C}$ after 6 weeks did not flower as much as expected from the dissection results in Table 3. The presence of wilted flower rudiments in several buds of these trees indicates that this might be a result of flower abortion of less developed flower primordia during cold storage and/ or flower development. Except from delayed flowering in trees from $12{ }^{\circ} \mathrm{C}$ (and ambient temperature in 'Discovery'), time of blooming (anthesis) was not significantly affected by the temperature treatments in 2017. The total number of nodes per tree increased with increasing temperature all the way up to $27^{\circ} \mathrm{C}$, a response that also affected the number of flower clusters per tree (Table 4).

Since two trees per treatment is marginal for the statistical testing of significance of effects, and since there was no cultivar effects and no interactions between cultivars and temperature treatments for most variables (Table 4), we also run an additional ANOVA with the results of the two cultivars combined (giving four replicate trees per treatment). The results presented in Table 5, likewise revealed highly significant effects of temperature on percentage of flowering nodes as well as number of flowers and flower clusters per tree.

\section{Discussion}

The results of these experiments show consistent and significant effects of summer temperature on growth and floral initiation in the apple cultivars 'Summered' and 'Discovery' over 2 years. A hyperbolic temperature response curve for flower formation over the $12{ }^{\circ} \mathrm{C}$ to $27{ }^{\circ} \mathrm{C}$ range was established with an optimum at 18 to $21{ }^{\circ} \mathrm{C}$ and little or no flowering at 12 and $27^{\circ} \mathrm{C}$ (Figs. 5, 
Table 3 The influence of constant and changing temperatures on the percentage of reproductive buds and the mean floral development stage of dissected buds of spurs and extension shoots of the apple cultivars 'Summerred' and 'Discovery' after completion of 12 weeks of exposure to the indicated temperatures (2017 experiment)

\begin{tabular}{|c|c|c|c|c|c|}
\hline \multirow[t]{2}{*}{ Cultivar } & \multirow[t]{2}{*}{ Temperature $\left({ }^{\circ} \mathrm{C}\right)$} & \multicolumn{2}{|l|}{ Spurs } & \multicolumn{2}{|l|}{ Extension shoots } \\
\hline & & $\begin{array}{l}\text { Generative buds } \\
\text { (\%) }\end{array}$ & $\begin{array}{l}\text { Mean floral development } \\
\text { stage }(1-7)^{\mathrm{a}}\end{array}$ & $\begin{array}{l}\text { Generative buds } \\
\text { (\%) }\end{array}$ & $\begin{array}{l}\text { Mean floral } \\
\text { development } \\
\text { stage (1-7) }\end{array}$ \\
\hline \multirow[t]{9}{*}{ 'Summerred' } & $12^{\circ} \mathrm{C}$ cont. & $3.7 e^{b}$ & $1.1 \mathrm{~d}$ & $0.0 \mathrm{~d}$ & $1.0 \mathrm{~b}$ \\
\hline & $18^{\circ} \mathrm{C}$ cont. & $97.6 \mathrm{a}$ & $6.5 \mathrm{a}$ & $41.1 \mathrm{a}$ & $5.0 \mathrm{a}$ \\
\hline & $24^{\circ} \mathrm{C}$ cont. & $73.6 b$ & $4.8 \mathrm{~b}$ & $39.6 \mathrm{a}$ & $4.5 \mathrm{a}$ \\
\hline & $27^{\circ} \mathrm{C}$ cont. & $21.0 \mathrm{~d}$ & $1.6 \mathrm{~cd}$ & $18.5 b$ & $1.8 \mathrm{~b}$ \\
\hline & Ambient & $48.0 \mathrm{C}$ & $2.3 c$ & $4.8 \mathrm{C}$ & $1.3 \mathrm{~b}$ \\
\hline & $12 \longrightarrow 24^{\circ} \mathrm{C}$ & $49.8 B$ & $2.4 \mathrm{~B}$ & $27.6 \mathrm{C}$ & $2.9 \mathrm{~B}$ \\
\hline & $18 \longrightarrow 27^{\circ} \mathrm{C}$ & $31.3 \mathrm{C}$ & $1.9 \mathrm{~B}$ & $15.0 \mathrm{D}$ & $3.0 \mathrm{~B}$ \\
\hline & $24 \longrightarrow 12^{\circ} \mathrm{C}$ & $64.6 \mathrm{~A}$ & $4.6 \mathrm{~A}$ & $50.8 \mathrm{~B}$ & $4.0 \mathrm{~A}$ \\
\hline & $27 \longrightarrow 18^{\circ} \mathrm{C}$ & $66.4 \mathrm{~A}$ & $4.6 \mathrm{~A}$ & $62.2 \mathrm{~A}$ & $3.7 \mathrm{~A}$ \\
\hline \multirow[t]{9}{*}{ 'Discovery' } & $12^{\circ} \mathrm{C}$ cont. & $3.7 c$ & $1.1 \mathrm{c}$ & $0.0 c$ & $1.0 \mathrm{c}$ \\
\hline & $18^{\circ} \mathrm{C}$ cont. & $100 \mathrm{a}$ & $5.6 \mathrm{a}$ & $26.5 b$ & $2.6 \mathrm{a}$ \\
\hline & $24^{\circ} \mathrm{C}$ cont. & $82.7 b$ & $4.4 \mathrm{~b}$ & $33.1 \mathrm{a}$ & $1.7 b$ \\
\hline & $27^{\circ} \mathrm{C}$ cont. & $2.3 c$ & $1.1 \mathrm{c}$ & $0.0 c$ & $1.0 \mathrm{c}$ \\
\hline & Ambient & $0.0 d$ & $1.0 \mathrm{c}$ & $0.0 c$ & $1.0 \mathrm{c}$ \\
\hline & $12 \longrightarrow 24^{\circ} \mathrm{C}$ & $0.0 \mathrm{C}$ & $1.0 \mathrm{C}$ & $0.0 \mathrm{~B}$ & $1.0 \mathrm{~B}$ \\
\hline & $18 \longrightarrow 27^{\circ} \mathrm{C}$ & $0.0 \mathrm{C}$ & $1.0 \mathrm{C}$ & $0.0 \mathrm{~B}$ & $1.1 \mathrm{~B}$ \\
\hline & $24 \longrightarrow 12^{\circ} \mathrm{C}$ & $56.6 \mathrm{~B}$ & $3.7 \mathrm{~B}$ & $22.7 \mathrm{~A}$ & $2.0 \mathrm{~A}$ \\
\hline & $27 \longrightarrow 18^{\circ} \mathrm{C}$ & $86.9 \mathrm{~A}$ & $4.9 \mathrm{~A}$ & $23.8 \mathrm{~A}$ & $2.1 \mathrm{~A}$ \\
\hline \multicolumn{6}{|c|}{ Probability level of significance by ANOVA } \\
\hline \multicolumn{6}{|c|}{ Source of variation } \\
\hline Cultivar (A & & $<0.001$ & $<0.001$ & 0.001 & 0.001 \\
\hline Temperatı & & $<0.001$ & $<0.001$ & $<0.001$ & $<0.001$ \\
\hline$A \times B$ & & $<0.001$ & $<0.001$ & $<0.001$ & $<0.001$ \\
\hline
\end{tabular}

The data are means of all spur buds from each of three replicate trees and of 15 lateral buds from the middle part of 3 extension shoots from each tree

a Stage 1 denotes entirely vegetative buds, and stage 7 denotes fully differentiated primary flowers

b For separation of means, Tukey's multiple comparison test was performed separately for the two cultivars (lower case letters), and likewise for constant and changing temperatures (capital letters)

6). This agrees with the results of Abbot et al. (1975), who found that FBF benefits from raising temperatures up to $18{ }^{\circ} \mathrm{C}$ at full bloom and shortly afterwards, and the results of Zhu et al. (1997) who found that increasing temperature in the $13-20^{\circ} \mathrm{C}$ range increased $\mathrm{FBF}$ in the cultivar 'Summerred'. Identical responses of trees grown at $12{ }^{\circ} \mathrm{C}$ in the phytotron and those grown at closely similar temperatures outdoors, provide strong support for the validity of the phytotron results. The usefulness of testing the whole range of realistic temperatures was clearly demonstrated by our two experiments, and the results may explain why both positive and negative temperature flowering responses were obtained in many previous studies, depending on which part of the relevant temperature range that was tested (Tromp 1976, 1980, 1984; Verheij 1996; Zhu et al. 1997).
In addition, there was also a distinct enhancement of flowering when the trees were transferred from high to low temperature after 6 weeks, compared with continued high temperatures or the opposite shift in temperature (Tables 2,3 ). The effects were particularly marked in 2017 when the wider range of temperatures was tested. The response to lowered temperature was associated with a parallel cessation of shoot growth (Fig. 4). This concurs with the growth cessation effect of low temperature demonstrated in apple rootstocks by Heide and Prestrud (2005), with one important qualification: It seems not to be low temperature as such that causes the growth cessation, but rather a drop in temperature. Thus, when the trees were grown at constant $12{ }^{\circ} \mathrm{C}$ from the very beginning in spring, they maintained continuous growth throughout the summer, whereas a marked drop in temperature resulted in growth cessation, even 
Table 4 Influence of constant and changing temperatures on shoot structure and flowering of apple trees as assessed by out-door performance in the subsequent spring following overwintering in a cold store at $1^{\circ} \mathrm{C}$ ( 2017 experiment)

\begin{tabular}{|c|c|c|c|c|c|c|c|c|c|}
\hline Cultivar & $\begin{array}{l}\text { Temperature } \\
\left({ }^{\circ} \mathrm{C}\right)\end{array}$ & $\begin{array}{l}\text { Flowering } \\
\text { nodes (\%) }\end{array}$ & $\begin{array}{l}\text { Vegetative } \\
\text { nodes (\%) }\end{array}$ & $\begin{array}{l}\text { Non- } \\
\text { breaking } \\
\text { nodes (\%) }\end{array}$ & $\begin{array}{l}\text { Nodes } \\
\text { per tree }\end{array}$ & $\begin{array}{l}\text { Flower } \\
\text { clusters } \\
\text { per tree }\end{array}$ & $\begin{array}{l}\text { Flowers } \\
\text { per tree }\end{array}$ & $\begin{array}{l}\text { Flowers } \\
\text { per cluster }\end{array}$ & $\begin{array}{l}\text { Days } \\
\text { to anthesis } \\
\text { from Apr. } 27^{a}\end{array}$ \\
\hline \multirow[t]{9}{*}{ 'Summerred' } & $12^{\circ} \mathrm{C}$ cont. & $9.0 c^{b}$ & $82.2 \mathrm{a}$ & $8.8 b$ & $158.0 \mathrm{~b}$ & $14.3 \mathrm{~d}$ & $41.0 \mathrm{C}$ & $2.9 b c$ & $33.0 \mathrm{a}$ \\
\hline & $18^{\circ} \mathrm{C}$ cont. & $67.2 \mathrm{a}$ & $19.1 \mathrm{c}$ & $13.7 \mathrm{ab}$ & $165.0 \mathrm{~b}$ & $111.0 \mathrm{~b}$ & $455.0 \mathrm{a}$ & $4.1 \mathrm{a}$ & $27.0 \mathrm{bc}$ \\
\hline & $24^{\circ} \mathrm{C}$ cont. & $41.4 b$ & $30.1 \mathrm{c}$ & $28.6 \mathrm{ab}$ & 395.7 a & $164.0 \mathrm{a}$ & $491.3 \mathrm{a}$ & $3.0 \mathrm{bc}$ & $26.7 c$ \\
\hline & $27^{\circ} \mathrm{C}$ cont. & $14.1 \mathrm{c}$ & $53.1 \mathrm{~b}$ & $32.8 \mathrm{a}$ & $401.3 \mathrm{a}$ & $54.7 \mathrm{C}$ & $142.3 \mathrm{~b}$ & $2.7 c$ & $28.3 \mathrm{bc}$ \\
\hline & Ambient & $15.4 \mathrm{C}$ & $68.1 \mathrm{ab}$ & $16.5 \mathrm{ab}$ & 196.5 b & $30.5 \mathrm{c}$ & $113.0 \mathrm{~b}$ & $3.7 \mathrm{ab}$ & $29.5 b$ \\
\hline & $12 \longrightarrow 24^{\circ} \mathrm{C}$ & $29.6 \mathrm{~A}$ & $50.4 \mathrm{~A}$ & $20.0 \mathrm{~A}$ & $232.0 \mathrm{~A}$ & 69.5 B & 211.5 B & $3.0 \mathrm{~A}$ & $27.0 \mathrm{~A}$ \\
\hline & $18 \longrightarrow 27^{\circ} \mathrm{C}$ & $30.7 \mathrm{~A}$ & $45.5 \mathrm{AB}$ & $23.8 \mathrm{~A}$ & $243.0 \mathrm{~A}$ & $76.0 \mathrm{~B}$ & 281.5 B & $4.0 \mathrm{~A}$ & $28.0 \mathrm{~A}$ \\
\hline & $24 \longrightarrow 12^{\circ} \mathrm{C}$ & $30.8 \mathrm{~A}$ & $48.7 \mathrm{~A}$ & $20.5 \mathrm{~A}$ & $187.5 \mathrm{~A}$ & $58.5 \mathrm{~B}$ & 230.5 B & $4.0 \mathrm{~A}$ & $26.5 \mathrm{~A}$ \\
\hline & $27 \longrightarrow 18^{\circ} \mathrm{C}$ & $41.6 \mathrm{~A}$ & 29.8 B & $28.7 \mathrm{~A}$ & $312.5 \mathrm{~A}$ & $130.0 \mathrm{~A}$ & $469.5 \mathrm{~A}$ & $3.6 \mathrm{~A}$ & $27.0 \mathrm{~A}$ \\
\hline Mean & & 29.7 & 48.5 & 21.8 & 263.7 & 78.6 & 264.1 & 3.4 & 28.3 \\
\hline \multirow[t]{9}{*}{ 'Discovery' } & $12^{\circ} \mathrm{C}$ cont. & $0.5 b c$ & $65.6 \mathrm{ab}$ & $33.9 c$ & 215.5 a & $1.0 \mathrm{c}$ & $3.0 \mathrm{c}$ & $1.5 \mathrm{c}$ & $65.0 \mathrm{~b}$ \\
\hline & $18^{\circ} \mathrm{C}$ cont. & $37.4 a$ & $27.7 b c$ & $34.9 b c$ & 265.3 a & $89.0 \mathrm{a}$ & 331.7 a & $3.7 \mathrm{a}$ & $28.0 \mathrm{a}$ \\
\hline & $24^{\circ} \mathrm{C}$ cont. & $22.2 \mathrm{a}$ & $22.9 c$ & $54.9 \mathrm{ab}$ & $326.0 \mathrm{a}$ & $74.0 \mathrm{a}$ & $200.5 \mathrm{a}$ & $2.8 \mathrm{~b}$ & $26.5 \mathrm{a}$ \\
\hline & $27^{\circ} \mathrm{C}$ cont. & $6.5 \mathrm{ab}$ & $27.1 \mathrm{C}$ & $66.5 a$ & $397.0 \mathrm{a}$ & $26.0 \mathrm{~b}$ & $74.5 \mathrm{~b}$ & $2.9 \mathrm{~b}$ & $30.5 \mathrm{a}$ \\
\hline & Ambient & $3.6 \mathrm{~b}$ & $68.3 \mathrm{a}$ & $28.1 \mathrm{C}$ & $241.5 \mathrm{a}$ & $8.5 \mathrm{c}$ & $20.0 c$ & $2.3 \mathrm{bc}$ & $37.0 \mathrm{a}$ \\
\hline & $12 \longrightarrow 24^{\circ} \mathrm{C}$ & $0.0 \mathrm{C}$ & $63.3 \mathrm{~A}$ & 36.7 B & 187.5 B & $0.0 \mathrm{C}$ & $0.0 \mathrm{C}$ & $0.0 \mathrm{~B}$ & $>100 \mathrm{~A}$ \\
\hline & $18 \longrightarrow 27^{\circ} \mathrm{C}$ & $4.6 \mathrm{~B}$ & $45.2 \mathrm{~A}$ & $50.3 \mathrm{~A}$ & $337.5 \mathrm{~A}$ & $14.5 \mathrm{~B}$ & $23.5 \mathrm{~B}$ & $0.8 \mathrm{AB}$ & $66.0 \mathrm{~B}$ \\
\hline & $24 \longrightarrow 12^{\circ} \mathrm{C}$ & $11.3 \mathrm{AB}$ & $48.0 \mathrm{~A}$ & $40.6 \mathrm{~A}$ & $341.5 \mathrm{~A}$ & $38.5 \mathrm{AB}$ & $122.5 \mathrm{AB}$ & $3.2 \mathrm{~A}$ & $30.5 B$ \\
\hline & $27 \longrightarrow 18^{\circ} \mathrm{C}$ & $19.1 \mathrm{~A}$ & $28.8 \mathrm{~B}$ & $52.1 \mathrm{~A}$ & $399.0 \mathrm{~A}$ & $65.5 \mathrm{~A}$ & $283.5 \mathrm{~A}$ & $4.5 \mathrm{~A}$ & $29.5 B$ \\
\hline Mean & & 13.0 & 43.2 & 43.7 & 299.3 & 38.1 & 128.9 & 2.5 & 39.1 \\
\hline \multicolumn{10}{|c|}{ Probability level of significance by ANOVA } \\
\hline \multicolumn{10}{|c|}{ Source of variation } \\
\hline Cultivar (A) & & ns & ns & ns & ns & ns & ns & 0.05 & 0.001 \\
\hline $\begin{array}{r}\text { Tempera- } \\
\text { ture (B) }\end{array}$ & & $<0.001$ & $<0.001$ & 0.01 & $<0.001$ & $<0.001$ & $<0.001$ & 0.02 & 0.04 \\
\hline$A \times B$ & & 0.003 & ns & ns & ns & ns & ns & ns & ns \\
\hline
\end{tabular}

The data are means of two trees from each treatment

a For non-flowering trees, number of days is set to 100

${ }^{\mathrm{b}}$ For separation of means, Tukey's multiple comparison test was performed separately for the two cultivars (lower case letters), and likewise for constant and changing temperatures (capital letters)

at considerably higher temperature levels (Figs. 3, 4). This conclusion is also compatible with the results of Heide and Prestrud (2005), who raised their plants at $21^{\circ} \mathrm{C}$ and then subsequently exposed them to varying lower temperatures, which apparently was sensed by the plants as a temperature drop and resulted in immediate growth cessation.

Association of floral initiation with growth cessation in apple as demonstrated in the present experiments (Tables 2, 3; Fig. 4) concurs with the conclusions of Luckwill (1970) and Hanke et al. (2007), and supports the suggestion by Rivero et al. (2017) that a late-summer drop in temperature may be involved in floral initiation in apple under field conditions. Likewise, in warm apple production areas, where floral initiation in apple is late (Gur 1985), a late-season drop in temperature was reported to be crucial for next year's apple crop (Zatyko 1974).
An association of growth cessation and floral initiation is also well known in other woody Rosaceae species such as raspberry and blackberry (Heide and Sønsteby 2011), in which growth cessation and floral initiation occur simultaneously and are jointly controlled by low temperature and short days. Note however, that although Zhu et al. (1997) also observed an immediate growth cessation when the temperature was dropped from $27{ }^{\circ} \mathrm{C}$ to $13{ }^{\circ} \mathrm{C}$ in 'Summerred', the effect was associated with suppression of flowering in their experiment.

Divergent connections between growth and flowering in apple have previously been reported in several studies (Gur 1985; Hanke et al. 2007 and references therein). With a few exceptions (e.g. Verheij 1996), the relation has generally been considered to be antagonistic. However, a more complex relationship is revealed by the present experiments. As concluded by Luckwill (1975), 
Table 5 Influence of constant and changing temperatures on shoot structure and flowering of apple trees as assessed by out-door performance in the subsequent spring following overwintering in a cold store at $1^{\circ} \mathrm{C}(2017$ experiment)

\begin{tabular}{lllllll}
\hline Temperature $\left({ }^{\circ} \mathrm{C}\right)$ & $\begin{array}{l}\text { Flowering } \\
\text { nodes (\%) }\end{array}$ & $\begin{array}{l}\text { Vegetative } \\
\text { nodes (\%) }\end{array}$ & $\begin{array}{l}\text { Non-breaking } \\
\text { nodes (\%) }\end{array}$ & Nodes per tree & $\begin{array}{l}\text { Flower cluster } \\
\text { per tree }\end{array}$ & $\begin{array}{l}\text { Flowers } \\
\text { per tree }\end{array}$ \\
\hline $12^{\circ} \mathrm{C}$ cont. & $5.6 \mathrm{~d}^{\mathrm{a}}$ & $75.2 \mathrm{a}$ & $18.8 \mathrm{~b}$ & $181.0 \mathrm{c}$ & $9.0 \mathrm{C}$ & $25.8 \mathrm{~b}$ \\
$18^{\circ} \mathrm{C}$ cont. & $49.3 \mathrm{a}$ & $24.2 \mathrm{~d}$ & $26.4 \mathrm{ab}$ & $225.2 \mathrm{bc}$ & $97.8 \mathrm{ab}$ & $381.0 \mathrm{a}$ \\
$24^{\circ} \mathrm{C}$ cont. & $33.7 \mathrm{ab}$ & $27.2 \mathrm{~d}$ & $39.1 \mathrm{ab}$ & $367.8 \mathrm{a}$ & $39.0 \mathrm{a}$ & $375.0 \mathrm{a}$ \\
$27^{\circ} \mathrm{C}$ cont. & $11.0 \mathrm{~cd}$ & $42.7 \mathrm{~cd}$ & $46.3 \mathrm{a}$ & $209.8 \mathrm{bc}$ & $34.8 \mathrm{bc}$ & $115.2 \mathrm{~b}$ \\
$12 \longrightarrow 24^{\circ} \mathrm{C}$ & $14.8 \mathrm{bcd}$ & $56.9 \mathrm{abc}$ & $28.3 \mathrm{ab}$ & $290.3 \mathrm{abc}$ & $45.3 \mathrm{bc}$ & $105.8 \mathrm{~b}$ \\
$18 \longrightarrow 27^{\circ} \mathrm{C}$ & $17.6 \mathrm{bcd}$ & $45.3 \mathrm{bcd}$ & $37.0 \mathrm{ab}$ & $264.5 \mathrm{abc}$ & $48.5 \mathrm{bc}$ & $152.5 \mathrm{~b}$ \\
$24 \longrightarrow 12^{\circ} \mathrm{C}$ & $21.1 \mathrm{bcd}$ & $48.4 \mathrm{bcd}$ & $30.6 \mathrm{ab}$ & $355.8 \mathrm{ab}$ & $97.8 \mathrm{ab}$ & $176.5 \mathrm{ab}$ \\
$27 \longrightarrow 18^{\circ} \mathrm{C}$ & $30.3 \mathrm{abc}$ & $29.3 \mathrm{~d}$ & $40.4 \mathrm{ab}$ & $219.0 \mathrm{bc}$ & $19.5 \mathrm{C}$ & $376.5 \mathrm{a}$ \\
Ambient & $9.5 \mathrm{~cd}$ & $68.2 \mathrm{ab}$ & $22.3 \mathrm{ab}$ & 280.6 & 56.3 & $66.5 \mathrm{~b}$ \\
Mean & 21.8 & 46.0 & 32.2 & $<0.001$ & $<0.001$ & 199.9 \\
$P$-value & $<0.001$ & $<0.001$ & 0.03 & & $<.001$
\end{tabular}

The data are means of four trees from each treatment

a All values are means of four replications, with one three in each treatment. Mean values in the same column followed by different lower-case letters are significantly different $(P \leq 0.005)$ for the different temperature treatments

the growing apple shoot must form a certain number of leaves before it may respond to environmental factors and initiate floral primordia. Because of the general temperature enhancement of leaf initiation (Figs. 3, 4b, d), shoot growth was promoted by increasing temperature. However, continued high temperature did not result in floral initiation unless the plants were subsequently exposed to a growth-terminating temperature drop (Table 3). Thus, there seems to be two different effects of temperature on FBF in apple, an early and indirect effect of high temperature enhancing growth and accumulation of the critical number of leaves, and a second and direct effect of low temperature triggering growth cessation and floral initiation itself. Our interpretation of the results in Figs. 5 and 6 is therefore, that at $12{ }^{\circ} \mathrm{C}$ and the ambient control treatments, FBF was limited by low temperature retardation of growth and leaf production, while at $27^{\circ} \mathrm{C}$; FBF was limited by inhibition of the floral initiation itself. On the other hand, the optimum temperature area of $18-21^{\circ} \mathrm{C}$ (Figs. 5, 6) seems to satisfy the requirements for both processes. It is likely that such a dual temperature effect on FBF in apple might have confounded the interpretation of experimental temperature results on FBF in apple in the past (Gur 1985; Hanke et al. 2007 and references therein).

In view of the marked effect of temperature on the rate of leaf initiation in apple, the biological relevance of the plastochron as a determinant of FBF in apple may also be questioned. Thus, Verheij (1996) found that although a number of factors affected FBF, only temperature and defoliation affected the plastochron. Based on these results, Verheij concluded that the plastochron is not a critical factor for FBF in apple. Thus, the reported plastochron effect may in fact just be an artefact appearing as a consequence of temperature-enhanced rate of leaf accumulation.

The poor flowering performance of the apple cultivars at $12{ }^{\circ} \mathrm{C}$ is highly compatible with the irregular and marginal flowering performance of apple trees in the cool Nordic climate and the geographical limits for commercial apple cultivation. (Jonkers 1979; Rivero et al. 2017). The results of a recent and comprehensive field investigation by Kofler et al. (2019) also concurs with these results. In an earlier publication (Rivero et al. 2017), we could show that, in the Northern climate, the time between bloom and the initiation of new floral primordia is considerably shorter than at lower and warmer latitudes. Therefore, we concluded that the marginal length of this period in cool climates, might be limiting for shoot maturation in apple, and hence, for timely production of the critical number of leaves and FBF in the cool Nordic climate. The results of the present experiments are in full agreement with this suggestion. On the other hand, in warm climatic regions, floral initiation in apple is delayed (Gur 1985), and under such conditions, a late period of cooler temperature in September was found to be crucial for the production of a decent crop in the next year (Zatyko 1974). This concurs with the poor flowering we obtained at $27^{\circ} \mathrm{C}$, and the consistent flowering resulting from a subsequent drop in temperature (Tables 2, 3).

An important reason for the clear-cut results of the present experiments (Figs. 5, 6) was the extensive use of bud dissections for assessment of the flowering response. The present results demonstrate that a late season drop in temperature can readily trigger floral initiation (Table 3 ). It is also well established in the literature (Gur 1985; 
Hanke et al. 2007), that flower bud differentiation in apple continues throughout late summer and autumn, and even into winter and spring. Therefore, large changes in flowering status may take place after completion of an experimental treatment, if the trees are subsequently moved outdoors and tested for flower performance in the following spring as commonly practiced (e.g. Tromp 1976, 1984; Verheij 1996). It is therefore important that the flowering status be assessed by dissections immediately after completion of the treatments as done in the present experiments. Furthermore, the results of the 2017 experiment showed that even when the trees were defoliated and moved directly into the cold store for overwintering and flowering in the spring, some flower bud abortion might also take place during winter chilling and flower development (Table 4). Late assessment of flowering by performance in the subsequent season may therefore give misleading information about the efficiency of the various floral induction treatments. It is also important that the trees be completely de-blossomed at start of the experiments in order to avoid confounding hormonal effects of developing fruits (cf. Chan and Cain 1967).

During recent decades, a wealth of information has become available regarding environmental and genetic factors regulating flowering in the annual model plant Arabidopsis thaliana (e.g. Jaeger and Wigge 2007; Notaguchi et al. 2008; Srikanth and Schmid 2011; Hanano and Goto 2011). In apple, two genes homologous to the TERMINAL FLOWER 1 (TFL1) gene in Arabidopsis (MdTFL1-1 and MdTFL1-2) were cloned and shown to function like TFL1 by maintaining the juvenile and vegetative state of the trees (Kotoda and Vada 2005; Kotoda et al. 2010; Flachowsky et al. 2012). The abundance of MdTFL1 transcripts in mature apple trees were shown to remain high in vegetative shoot apices during blooming in spring, to drastically decrease during the following period of floral initiation, and then to increase again after completion of FBF (Hättasch et al. 2008; Mimida et al. 2011). This was interpreted to indicate that MdTFL1 acts to prevent precocious flowering both in spring and in autumn, and thus to maintain the perennial growth cycle of the trees (Hättasch et al. 2008; Flachowsky et al. 2012). On the other hand, the transcript of two ortologs of the floral integrator gene in Arabidopsis (MdFT1/MdFT2) were found to have patterns of expression that are complementary to that of MdTFL1 and MdTFL2 (Kotoda et al. 2010). Thus, the MdFT1 transcript in apical buds of mature trees was upregulated from early June to late July at the time when transition from vegetative to reproductive development takes place, while overexpression of the gene resulted in precocious flowering.

Although the molecular processes involved are beyond the scope of the present paper, the dual and consistent effects of temperature demonstrated strongly suggest that the antagonistic action of $M d F T /$ $M d T F L 1$ is somehow involved. Fast leaf production and suppression of flowering by high temperature $\left(27^{\circ} \mathrm{C}\right)$ would be compatible with high expression of MdTFL1 and suppression of MdFT activation (cf. Figs. 4 and 5). On the other hand, low temperature, or a drop in temperature that causes growth cessation and the floral initiation proper, may involve the activation of $M d F T$ after formation of the critical number of leaves.

\section{Conclusion}

We highlight that the unique controlled environment experimental system used, which for the first time has given consistent and clear-cut flowering results in apple across cultivars and experiments, provide an excellent system for exploration of the molecular processes involved in the environmental control of growth and flower initiation in apple.

\section{Acknowledgements \\ We thank Unni M. Roos and Hans Gunnar Espelien for excellent technical assistance with the experiments.}

\section{Authors' contributions}

Professor Emer. OMH contributed to the design, the acquisition, and interpretation of the experiments, and did the major part of the writing of the manuscript. PhD student RIR contributed to the conception and design of the work, and to data collection, and interpretation of the results. Research Professor AS contributed to the design of the study, analysis and interpretation of data, and writing of the manuscript. All authors read and approved the final manuscript.

\section{Funding}

Not applicable.

\section{Availability of data and materials}

The datasets analysed during the current study are available from the corresponding author on reasonable request.

Ethics approval and consent to participate

Not applicable.

Consent for publication

Not applicable.

\section{Competing interests}

The authors declare that they have no competing interests.

\section{Author details}

${ }^{1}$ Faculty of Environmental Sciences and Natural Resource Management, Norwegian University of Life Sciences, 1432 Ås, Norway. ${ }^{2} \mathrm{NIBIO}$, Norwegian Institute of Bioeconomy Research, 1431 Ås, Norway.

Received: 27 April 2020 Accepted: 27 June 2020

Published online: 14 July 2020

\section{References}

Abbott DL, Bull V. The effect of autumn temperature on flower initiation and fruit bud development. Rep Long Ashton Res Stn. 1973;1972:34-5.

Abbott DL, Rubach M, Bishop SN. Factors influencing flower initiation. Rep Long Ashton Res Stn. 1975;1974:32-4. 
Auchter EC, Lagasse FS, Aldric WW. The effect of shade on the growth, fruit bud formation and chemical composition of apple trees. Proc Amer Soc Hortic Sci. 1926;23:368-2.

Bangerth F. Flower induction in perennial fruit trees: still an enigma? Acta Hortic. 2006;727:177-95.

Chain JC. Foliage canopy development of'McIntosh'apple hedgerows in relation to mechanical pruning, the interception of solar radiation and fruiting. J Amer Soc Hortic Sci. 1973;98:357-66.

Chan BG, Cain JC. The effect of seed formation on subsequent flowering. Proc Amer Soc Hortic Sci. 1967;91:63-8.

Crabbé J. Vegetative vigor control over location and fate of flower buds in fruit trees. Acta Hortic. 1984;149:55-63.

Davies MHE. Some trials on the effect of defoliation upon cropping of apples. Rep East Malling Res Stn. 1959;1959:53-9.

FAO Production Yearbook, 2017.

Flachowsky H, Szankowski I, Waidmann S, Peil A, Tränkner C, Hanke M-V. The MdTFL 1 gene of apple (Malus $\times$ domestica Borkh.) reduces vegetative growth and generation time. Tree Physiol. 2012;32:1288-301.

Forshey CG, Elfing DC. The relationship between vegetative growth and fruiting in apple trees. Hortic Rev. 1989;11:229-87.

Foster T, Johnston R, Seleznyova A. A morphological and quantitative characterization of early floral development in apple (Malus $\times$ domestica Borkh.). Ann Bot. 2003;92:199-206.

Fulford RM. The morphogenesis of the apple buds. I. The activity of the apical meristem. Ann Bot. 1965;29:167-80.

Fulford RM. The morphogenesis of the apple buds. III. The inception of flower Ann Bot. 1966a;30:207-19.

Fulford RM. The morphogenesis of the apple buds. IV. The effect of fruit. Ann Bot. 1966b;30:597-606.

Gorter CJ. Photoperiodism of flowering in apple trees. Proc 14th Int Hortic Congr. 1955:1:351-4.

Gorter CJ. Photoperiodism of flowering in Lombartscalville apple. Hortic Res. 1965:5:32-5.

Gur A. Rosaceae-decidious fruit trees. In: Halevy AH, editor. Handbook of flowering, vol. I. Florida: CRC Press; 1985. p. 355-89.

Hanano S, Goto K. Arabidopsis TERMINAL FLOWER 1 is involved in the regulation of flowering time and inflorescence development through transcriptional repression. Plant Cell. 2011:23:3172-84.

Hanke V. Histologische Untersuchungen zur Blütenknospendifferenzierung bei Malus $\times$ domestica Bockh. ('Golden Delicious'). PhD Thesis, Akademie der Landwirtschaftswissenschaften DDR. 1981.95 pp.

Hanke M-V, Flachowsky H, Peil A, Hättasch C. No flower no fruit-genetic potentials to trigger flowering in fruit trees. Genes Genomes Genomics. 2007;1(1):1-20.

Hättasch C, Flachowsky H, Kapturska D, Hanke M-V. Isolation of flowering genes and seasonal changes in their transcript levels related to flower induction in apple (Malus domestica). Tree Physiol. 2008;28:1459-66.

Heide OM, Prestrud AK. Low temperature, but not photoperiod, controls growth and dormancy induction in apple and pear. Tree Physiol. 2005;25:109-14.

Heide OM, Sønsteby A. Physiology of flowering and dormancy regulation in annual- and biennial-fruiting red raspberry (Rubus idaeus L.) - a review. J Hortic Sci Biotech. 2011:86:433-42.

Hoyle DA. Preliminary studies on the growth of fruit plants in relation to photoperiod. Proc 14th Int Hortic Congr. 1955;1:342-50.

Jackson IE, Palmer IW. Effects of shade on the growth of apple trees. II. Effects on components of yield. J Hortic Sci. 1977;52:253-66.

Jaeger KE, Wigge PA. FT protein acts as a long-range signal in Arabidopis. Curr Biol. 2007;17:1050-4.

Jonkers H. Biennial bearing in apple and pear: a literature survey. Sci Hortic 1979;11:303-17.

Kofler J, Milyaev A, Capezzone F, Stojnic S, Micic N, Flachowsky H, Hanke M-V, Wünsche J-N. High crop load and low temperature delay the onset of bud initiation in apple. Sci Rep. 2019. https://doi.org/10.1038/s4159 8-019-54381-x.

Kotoda N, Wada M. MdTFL 1, a TFL1 like gene of apple, retards the transition from the vegetative to reproductive phase in transgenic Arabidopsis. Plant Sci. 2005;168:95-104

Kotoda N, Hayashi H, Suzuki M, Igarashi M, Hatsayama Y, Kidou S-I, Igasaki T, Nishiguchi M, Yano K, Shimizu T, Takahashi S, Moriya S, Abe S.
Molecular characterization of FLOWERING LOCUS T-like genes of apple (Malus $\times$ domestica Borkh.). Plant Cell Physiol. 2010;51:561-75.

Kurokura T, Mimida N, Battey NH, Hytönen T. The regulation of seasonal flowering in the Rosaceae. J Exp Bot. 2013;64:4131-41.

Lakso AN. Correlation of fisheye photographs to canopy structure, light climate, and biological responses to light in apple trees. J Amer Soc Hortic Sci. 1980;105:43-6.

Lang A. Physiology of flower initiation. In: Ruhland W, editor. Encyclopedia. Plant Physiol, vol. 15. Berlin: Springer; 1965. p. 1380-536.

Luckwill LC. The control of growth and fruitfulness of apple trees. In: Luckwill C, Cutting CV, editors. Physiology of tree crops. London: Academic Press; 1970. p. 237-54.

Luckwill LC. A new look at the process of fruit bud formation in apple. Proc 19th Int Hortic Congr (Warsaw). 1975;3:237-45.

Luckwill LC, Silva LM. The effect of daminozide and gibberellic acid on flower initiation, growth and fruiting of apple cv. Golden Delicious. J Hortic Sci. 1969;54:217-23.

Magness JR, Fletcher LA, Aldrich WW. Time during which fruit bud formation in apples may be influenced in the Shenandoah-Cumberland fruit districts. Proc Amer Soc Hortic Sci. 1933:30:313-8.

McLaughlin JW, Green DW. Fruit and hormones influence flowering of apple.I. Effect of cultivar. J Amer Soc Hortic Sci. 1991;116:446-9.

Mimida N, Ureshino A, Tanaka N, Shigeta N, Sato N, Moriya-Tanaka Y, Iwanami H, Honda C, Suzuki A, Komori S, Wada M. Expression patterns of several floral genes during flower initiation in the apical buds of apple (Malus $\times$ domestica Borkh.) revealed by in situ hybridization. Plant Cell Rep. 2011;30:1485-92.

Notaguchi M, Abe M, Kimura T, Daimon Y, Kobayashi T, Yamaguchi A, Tomita Y, Dohi K, Mori M, Araki T. Long-distance, graft-transmissible action of Arabidopsis FLOWERING LOCUS T protein to promote flowering. Plant Cell Physiol. 2008:49:1645-58.

Paddock W, Charles FC. The effect of shade upon fruit bud differentiation. Proc Amer Soc Hortic Sci. 1928;25:195-7.

Piringer AA, Downs RJ. Responses of apple and peach trees to various photoperiods. Proc Amer Soc Hortic Sci. 1959;80:27-37.

Rivero R, Sønsteby A, Heide OM, Måge F, Remberg SF. Flowering phenology and the interrelations between phenological stages in apple trees (Malus domestica Borgh.) as influenced by the Nordic climate. Acta Agric Scand Sect B Soil Plant Sci. 2017;67:292-302.

Singh LB. Studies on biennial bearing. II. A review of the literature. J Hortic Sci. 1948;24:45-65

Srikanth A, Schmid M. Regulation of flowering time: all roads led to Rome. Cell Mol Life Sci. 2011;68:2013-37.

Tromp J. Flower-bud formation and shoot growth in apple as affected by temperature. Sci Hortic. 1976;5:331-8.

Tromp J. Flower-bud formation in apple under various day and night temperature-regimes. Sci Hortic. 1980;13:235-43.

Tromp J. Flower-bud formation in apple as affected by air and root temperature, air humidity, light intensity, and day length. Acta Hortic. 1984;149:39-47.

Verheij FA. Morphological and physiological aspects of the early phases of flower bud formation of apple. PhD Thesis, Wageningen Univ. Wageningen: The Netherlands; 1996. pp. 148.

Visser T. Juvenile phase and growth of apple and pear seedlings. Euphytica. 1964;13:119-29.

Zatyko I. The autumn flower bud initiation in apple. Proc 19th Int Hortic Congr. Warsaw. 1974;1B:59.

Zeller O. Entwicklungsgeschichte der Blütenknospen und Fruchtanlagen an einjahrigen Langtrieben von Apfelbüschen. I. Entwicklungsverlauf und Entwicklungsmorphologie der Blüten am einjahrigen Langtrieb. Zeitschr Pflanzensücht. 1960;44:243-78.

Zhu LH, Borsboom O, Tromp J. The effect of temperature on flower-bud formation in apple including some morphological aspects. Sci Hortic. 1997:70:1-8.

Zimmerman $\mathrm{RH}$. Juvenility and flowering in woody plants: a review. HortScience. $1972: 10: 447-55$

\section{Publisher's Note}

Springer Nature remains neutral with regard to jurisdictional claims in published maps and institutional affiliations. 